\title{
Prolaps Iris dan Konjungtivitis pada Kucing
}

\author{
Iris Prolapse and Conjunctivitis on Cats
}

\author{
Aidil Akbar Saimima1 ${ }^{*}$, Damar Alam Purwastoko1, Putri Citrawati1 ${ }^{1}$ Ajeng Aeka² \\ 1Pendidikan Profesi Dokter Hewan, Fakultas Kedokteran Hewan, Universitas Brawijaya \\ ${ }^{2}$ Rumah Sakit Hewan Pendidikan, Fakultas Kedokteran Hewan, Universitas Brawijaya \\ *email: aidilakbarsaimima@gmail.com*
}

\begin{abstract}
ABSTRAK
Prolapsus iris adalah kondisi pada kornea yang mengalami perlukaan sehingga iris yang berada di bilik anterior mata keluar ke daerah ekstraokuler. Konjungtivitis dapat terjadi akibat kondisi yang ditimbulkan oleh prolaps iris. Pemeriksaan yang dilakukan pada pasien mencakup pemeriksaan fisik, pemeriksaan neurologis, dan uji halang rintang. Pemeriksaan menunjukkan hasil yaitu gangguan pada mata dextra unilateral yang tidak responsif terhadap uji neurologis. Pemeriksaan penunjang berupa uji hematologi digunakan untuk mengkaji kondisi pasien selama dua minggu perawatan. Terapi menggunakan Cendo Genta 1\% (gentamicin) s.4.d.d 1 gtt selama 10 hari, Otsu-NS ( $\mathrm{NaCl}$ 0,9\%) s.8.d.d 1-2 gtt selama perawatan, dan suplementasi multivitamin. Perawatan minggu pertama menunjukkan hasil yang cukup baik tetapi perawatan berikutnya tidak menunjukkan hasil signifikan. Prolaps iris berkurang sebesar $0,2 \mathrm{~cm}$ dari kondisi awal yakni 1,7 cm terhitung dari canthus lateral mata kanan. Terapi secara topikal tidak menunjukkan hasil signifikan dalam menangani kasus prolaps iris.

Kata kunci: Iris, Konjungtivitis, Kucing, Laserasi, Prolaps
\end{abstract}

\section{ABSTRACT}

Iris prolapse is a condition of cornea which suffered a trauma that allows iris from anterior chamber to move into extraocular space. Conjunctivitis can be a secondary sign due to iris prolapse. The examination that was conducted includes physical examination, neurologic examination, and obstacle course. The result showed a impaired vision of the right eye unilaterally and not responsive during the neurologic exam. Additional examination was done to evaluate the patient's condition within 2 weeks of stay in hospital. The therapy that was used is getamicin (Cendo Genta 1\%) s.4.d.d $1 \mathrm{gtt}$ for 10 days, Otsu-NS ( $\mathrm{NaCl}$ 0,9\%) s.8.d.d 1-2 gtt during the stay, and vitamin supplementation. The first week of the stay showed decent progress but did not went any further during the rest of the stay. Iris prolapse was reduced by $0,2 \mathrm{~cm}$ compared to the initial which was $1,7 \mathrm{~cm}$ that counted from lateral canthus of the right eye. Topical teraphy was not effective againts the iris prolapse condition. Keywords: Cat, Conjunctivitis, Iris, Laceration, Prolapse

\section{PENDAHULUAN}

Mata merupakan organ transparan

pada tubuh yang memiliki fungsi untuk

memberi gambaran individu mengenai lingkungan sekitar. Banyak penyakit yang dapat menyebabkan gangguan pada mata hewan meliputi penyakit pada mata, penyakit 
sistemik, dan trauma. Ketika terjadi gejala yang dapat diamati pada mata, hal tersebut dapat membantu menentukan diagnosa awal dan dapat dilakukan kontrol lesi lebih awal. Penyebab penyakit mata yang umum dijumpai pada kucing yaitu panleukopenia, feline herpes virus, feline infectious peritonitis, feline leukaemia complex, feline calicivirus, klamidiosis, bartonellosis, tuberkulosis, toksoplasmosis, cryptococcosis, hipertensi, tetanus, dan berbagai gangguan lain (Roze, 2005). Trauma pada mata yang menimbulkan luka dapat terjadi baik di palpebrae, konjungtiva, maupun bola mata (Turner, 2009).

Kejadian laserasi akibat tercakar merupakan salah satu penyebab perlukaan mata yang sering terjadi. Prognosa dari kondisi tersebut bergantung dari keparahan luka, sudut luka, dan kedalaman luka berpengaruh. Kerusakan struktur mata yang bersifat superfisial ( $<1 / 3$ tebal kornea) lebih mudah sembuh dibandingkan kerusakan profundal ( $>2 / 3$ tebal kornea). Luka di tepi kornea lebih mudah sembuh dibandingkan perlukaan pada bagian tengah kornea.
Prognosis penyakit lebih bagus pada perlukaan superfisial tanpa perlukaan interna mata akibat tembusnya kornea. Perforasi yang kecil $(<2 \mathrm{~mm})$ dapat menutup kebocoran dengan membentuk gumpalan aqueous humor dan fibrin. Kerusakan yang lebih parah dapat mengurangi jumlah cairan pada bilik anterior mata, sehingga terjadi pergerakan iris ke bagian anterior untuk menutupi lubang dan terjadi sinesia. Pergerakan berlebih iris akan menyebabkan prolaps iris dan menonjol keluar melalui laserasi pada kornea.

\section{MATERI DAN METODE}

Kucing bernama Putih yang merupakan kucing jantan ras DSH (Domestic Short Hair) yang diselamatkan di Sidoarjo oleh klien dan dibawa ke RSHP Universitas Brawijaya di Malang untuk dilakukan pemeriksaan pada tanggal 3 September 2020. Hewan tersebut di bawa ke RSHP Brawijaya dengan kondisi mata kanan yang mengalami gangguan yakni penonjolan pada anterior mata. Riwayat penyakit dan kemungkinan 
etiologi penyebab abnormalitas pada mata tidak diketahui dikarenakan pasien yang merupakan kucing liar. Gangguan terhadap mata hanya terjadi unilateral yakni pada mata kanan yang terlihat kotro pada daerah sekitar mata dan tidak adanya respon berkedi dari palpebrae.

Pemeriksaan yang dilakukan meliputi pemeriksaan fisik secara umum, pemeriksaan neurologis, dan pemeriksaan pengelihatan. Pemeriksaan secara umum dilakukan dengan melakukan inspeksi, palpasi, dan auskultasi untuk memastikan kondisi pasien secara keseluruhan. Peelaksanaan pemeriksaan neurologis dilakukan dengan inspeksi akan keberadaan nystagmus, paresis otot wajah, hilangnya pendengaran, memiringkan kepala, perubahan perilaku, atau ataxia yang dapat mengindikasikan terjadinya trauma pada sistim syaraf pusat. Pengkajian pengelihatan pasien dilakukan dengan membuat jalur halang rintang dalam kondisi terang (photopic) dan redup (scotopic) disertai pemeriksaan nervus optikus melalui uji menace, dazzle, dan pupillary light reflexes.
Penonjolan pada mata diukur menggunakan penggaris berskala dan diukur dari canthus lateral dengan posisi lurus sejajar dengan posisi anterior mata.

$$
\text { Pengobatan yang dilakukan }
$$

mencakup pemberian pelembab mata, antibiotika, dan suplementasi multivitamin. Larutan yang digunakan untuk membersihkan dan melembabkan mata adalah Otsu - NS NaCl 0,9\% setiap 3 jam sekali pada mata kanan sebanyak 1-2 tetes. Antibiotik yang digunakan adalah Cendo Genta 1\% sterile eye drops setiap 6 jam sekali pada mata kanan sebanyak 1 tetes. Pemberian pelembab dilakukan disertai membersihkan kerak yang terbentuk dari eksudat di bagian dalam dan bagian luar mata menggunakan kasa steril yang dibasahi $\mathrm{NaCl} \quad 0.9 \%$. Pemberian antibiotik dimulai setelah semua kerak yang menempel pada mata sudah terlepas sehingga tidak ada bagian mata yang tertutupi. Suplemen yang digunakan sebagai multivitamin iCATS nutrition paste secara oral dengan cara melumatnya bersamaan dengan pemberian pakan. Pemberian pakan selama 
proses pemeliharaan menggunakan Me-O

kitten food dengan interval pemberian selama

2 kali dalam sehari. Air minum selalu tersedia

dan diganti bersamaan dengan proses pemberian pakan menggunakan air mineral dalam kemasan. Elizabeth's collar digunakan selama perawatan untuk mencegah terjadinya trauma pada mata.

\section{HASIL}

Berdasarkan hasil pemeriksaan fisik, diperkirakan kucing berusia sekitar 5-7 bulan karena gigi permanen telah lengkap dan penimbangan berat badan menunjukkan berat kucing yakni 800 gram. Pemeriksaan suhu memperlihatkan kisaran suhu pada $37,8^{\circ} \mathrm{C}$ disertai frekuensi pulsus 148 kali tiap menit dan frekuensi nafas 48 kali tiap menit. Status hidrasi pasien baik, ditandai dengan mukosa yang terlihat berwarna merah muda cerah dengan nilai capillary refill time (CRT) dan turgor kurang dari 2 detik. Hasil pemeriksaan organ rongga thorax dan organ rongga abdomen tidak menunjukkan adanya abnormalitas. Pengamatan dan pemeriksaan ekstremitas pada pasien menunjukkan kondisi pasien yang aktif dan tidak terjadi kejanggalan pada anggota gerak. Pemeriksaan limfonodul menunjukkan perubahan pada limfonodul submandibular dextra yang bersifat unilateral yang meliputi pembesaran ukuran dan peningkatan suhu dibandingkan dengan daerah sekitarnya.

Pemeriksaan pada mata dengan cara melakukan inspeksi menunjukkan daerah palpebrae yang kotor, memiliki noda akibat epiphora, dan memiliki kerak yang menutupi cilia pada tepian palpebrae. Kenampakan mata menunjukkan penojolan pada kornea yang diselubungi kerak kekuningan. Palpebrae pada mata kanan tidak bisa menutup dikarenakan terhalang oleh penonjolan pada kornea. Hasil pengamatan pada sklera menunjukkan warna merah kebiruan dengan limbus yang tidak berbatas jelas. Pemeriksaan pada mata kiri menunjukkan kondisi mata dan palpebrae yang bersih, serta terlihat kemampuan palpebrae untuk menutup dalam kondisi normal. Ukuran mata kiri dan kanan tidak mengalami perubahan dan berada dalam 
posisi normal. Posisi mata kiri dan kanan tidak mengalami perubahan, tetapi pengukuran jarak antara canthus lateral dan bagian anterior mata menunjukkan jarak sebesar 1,7 cm sedangkan pada mata kiri dalam kondisi normal menunjukkan jarak sebesar $0,5 \mathrm{~cm}$. Pemeriksaan konjungtiva kanan menunjukkan kondisi kemerahan dan peningkatan suhu di sekitar palpebra sehingga kucing mengalami konjungtivitis.

Pemeriksaan kondisi neurologis dan kemampuan melihat pasien dilaksanakan setelah pemeriksaan fisik selesai dilakukan. Kondisi gangguan neurologis dapat ditunjukkan dengan adanya kehilangan respon pendengaran, paresis muskulus wajah, kepala yang miring, perubahan sikap, dan ataksia (Turner, 2009). Pasien menunjukkan habitus yang normal dan terlihat aktif merespon baik terhadap panggilan. Pemeriksaan neurologis lanjutan yang dilakukan adalah pemeriksaan menace, dazzle, dan pupillary light reflex (PLR). Pemeriksaan menace menunjukkan tidak adanya respon pada mata kanan tetapi respon uji menace menunjukkan respon syaraf yang normal pada mata kiri. Pemeriksaan Dazzle dilakukan pada ruangan gelap dengan memancarkan cahaya terang pada mata, dimana mata kanan memberikan respon yang lemah dan mata kiri menunjukkan respon yang signifikan terhadap cahaya. Pemeriksaan PLR menunjukkan tidak ada respon pada mata kanan dan mata kiri menunjukkan respon yang baik. Uji halang rintang pada kondisi terang dan redup menunjukkan bahwa kucing masih dapat mengamati lingkungan dengan baik, sehingga gangguan pada mata dikategorikan menjadi gangguan mata unilateral dextra. Prognosa dari kasus yang ditangani adalah fausta.

\section{PEMBAHASAN}

Abnormalitas yang timbul pada mata kanan salah satunya adalah perubahan pada kontur kornea yang mengalami penonjolan. Perubahan kontur kornea dapat disebabkan oleh berbagai faktor mencakup laserasi total, laserasi parsial, pembentukan ulkus, adanya tumor orbita, dan prolaps iris (Turner, 2009). 
Pemeriksaan pasien menunjukkan penonjolan pada kornea, dimana keutuhan kornea sudah tidak terlihat dan tergantikan oleh bentukan penonjolan yang abnormal. Gangguan akibat terjadinya laserasi dan ulkus dapat diamati dari kondisi kornea yang memiliki cekungan atau lubang, tetapi pada pasien terjadi penonjolan ke daerah anterior. Pengkajian cekungan pada mata dapat menggunakan uji fluorescein dengan tujuan menentukan kedalaman cekungan apakah hanya mengikis stroma atau telah menembus membran descement (Williams, 2014). Pasien tidak menjalani uji fluorescein akibat keutuhan kornea yang telah berubah disertai penonjolan dari kornea sehingga mengindikasikan terjadinya pengeluaran struktur mata pada bilik anterior. Temuan pembuluh darah pada lokasi yang menonjol keluar dan kenampakan yang terlihat seperti muskulus mengindikasikan bahwa bagian tersebut merupakan iris yang keluar dari bilik anterior mata. Temuan bentukan rubeosis iridis yang merupakan hasil proliferasi dari pembuluh darah pada iris dapat terbentuk pada kasus inflamasi yang terdampak pada bilik anterior mata (Maddison et al., 2008). Perubahan pada kontur kornea disertai keluarnya iris mengindikasikan terjadinya prolaps iris yang dapat disebabkan akibat trauma pada mata.

Sklera dapat mengalami perubahan meliputi perubahan warna menjadi kemerahan, bengkak, dan terbentuknya massa pada struktur mata tersebut. Etiologi penyakit yang berkotribusi kepada perubahan kenampakan sklera meliputi infeksi, kongesti, hemoragi, alergi, kista, dan neoplasia (Turner, 2009). Sklera dapat mengalami abnormalitas yang terkait dengan perubahan sirkulasi darah secara lokal, misalnya pada kasus hemoraghi atau kongesti yang akan nampak dan mengubah kondisi normal sklera yang berwarna keputihan. Sklera memiliki suplai pembuluh darah dalam jumlah besar tetapi tidak mencolok sehingga tidak terlihat jelas, tetapi berbeda dengan kornea yang tidak memiliki suplai darah secara langsung. Hewan muda memiliki sklera yang lebih tipis lapisan sklera dibandingkan dengan hewan dewasa sehingga akan memberi kesan kebiruan 
(Englar, 2019). Perubahan warna sklera secara merata yang menunjukkan kemerahan dapat disebabkan oleh infeksi yang menimbulkan episkleritis. Kemerahan berbeda ditunjukkan apabila warna segar darah dijumpai pada sklera, dimana kondisi tersebut dapat terjadi akibat trauma sehingga terjadi hemoraghi pembuluh darah. Gejala inflamasi dapat bersifat sekunder dari kondisi glaukoma, keratitis, uveitis, atau terjadinya trauma (Englar, 2019) sehingga membuka celah untuk mikroorganisme dalam memicu reaksi inflamasi.

Kondisi prolaps iris menggangu penutupan palpebrae dalam melumasi mata dan mencegah masuknya benda asing yang berpotensi menyebabkan infeksi maupun alergi. Berkurangnya kelembaban mata dapat memicu terjadinya keringnya permukaan mata sehingga dapat menimbulkan gangguan misalnya keratoconjunctivitis sicca (KCS) (William, 2008). Pemberian air mata buatan dapat membantu menangani kondisi mata kering. Semakin rendah residensi okuler akan menimbulkan makin pendeknya interval pemberian pelembab mata, dimana residensi okuler yang paling rendah dimiliki oleh air mata buatan dengan sifat yang sangat encer. Residensi okuler yang tinggi dimiliki oleh larutan yang kental, tetapi dapat mengganggu pandangan dan proses berkedip (Johnson et al., 2006).

Dehidrasi mata dapat terjadi ketika terdapat penurunan kuantitas air mata pada permukaan mata ketika berkedip. Penggunaan benzalkonium klorida, klorbutanol, dan fenilmerkurik nitrat dapat berpotensi menimbulkan efek alergi dan mempengaruhi fibroblas sub-tenon dan permukaan mata pada beberapa individu. Larutan natrium klorida 0,9\% dapat digunakan sebagai pelembab mata dan meredakan rasa tidak nyaman dari mata yang kering (Barabino et al., 2005). Penggunaan asam hyaluronat lebih efektif ditinjau dari kemampuan residensi okuler dibandingkan dengan larutan yang lebih encer (Johnson et al., 2006). Residensi okuler yang tinggi akan menyebabkan kemampuan pelembab bertahan pada mata berlangsung jauh lebih 
lama dibandingkan dengan cairan yang lebih memiliki viskositas rendah, sehingga pengaruh utama dalam mempertahankan kelembaban dalam segi waktu ialah interval pemberian. Pemberian pelembab dilakukan pada awal proses pembersihan untuk membersihkan mata dari kotoran dengan tujuan apabila dilakukan pemberian antibiotik atau antiinflamasi dapat tersebar secara merata.

Kasus prolaps iris yang menandakan terjadinya kerusakan pada kornea mencegah penggunaan beberapa jenis obat. Penggunaan obat antiinflamasi non steroid (NSAID) untuk mengurangi inflamasi yakni menghambat enzim siklooksigenasi (COX) memiliki efek samping yakni menimbulkan ulserasi dan perforasi kornea (Iwamoto et al., 2017). Penggunaan obat golongan steroid perlu dihindari pada proses perlukaan kornea seperti NSAID karena membentuk ulkus dapat menghambat pertumbuhan jaringan dan memberi kesan berkabut pada kornea yang disertai kematian keratinosit (Sarchaci et al., 2011). NSAID menghambat pembentukan metabolit asam arakidonat melalui jalur COX dan mencegah pembentukan salah satu turunannya yaitu 12-HHT [Asam 12(s)hidroksiheptadeka-5Z,8E,10E-trienoik] yang merupakan ligan reseptor leukotrien B (BLT2). Hambatan pada reseptor BLT2 menurunkan migrasi sel epitel kornea sehingga penutupan epitel yang menentukan penutupan luka kornea terhambat (Iwamoto et al., 2017). Kasus prolaps iris yang mengindikasikan terjadi robeknya kornea menjadi kontra-indikasi penggunaan agen pengobatan tersebut sehingga membasmi agen penyebab inflamasi menjadi pilihan dalam kasus ini.

Peradangan secara lokal pada mata menjadi indikasi penggunaan antibiotik. Antibiotik yang digunakan yaitu Gentamicin dengan pemberian 4 kali senhari yakni 5 pagi, 11 siang, 5 sore dan 11 malam. Penggunaan gentamicin menunjukkan hasil yang baik dengan terhentinya produksi eksudat pada hari ke-2 pasca pemberian antibiotik. Gentamicin merupakan antibiotik yang sensitif terhadap bakteri terutama dari golongan gram-negatif dan golongan 
Staphylococcus (Plumb, 2011) yang menetap pada kulit yang berpotensi menimbulkan infeksi sekunder. Perkembangan terlihat pada hari ke-5 pasca pemberian gentamicin yakni kondisi mata yang bersih tanpa adanya kerak maupun eksudat. Pemberian gentamicin dihentikan setelah hari ke-5 dan dilakukan pemeriksaan darah untuk melakukan evaluasi kondisi kucing dan persiapan apabila dibutuhkan prosedur operatif apabila dalam kurun satu minggu. Hari ke-2 pasca penghentian pemberian gentamicin, mata mulai menunjukkan kembalinya produksi eksudat kembali. Tindakan yang dilakukan untuk menangani kondisi tersebut dengan melakukan terapi antibiotik kembali menggunakan Gentamicin yang menunjukkan terhentinya proses pengeluaran eksudat.

Tabel 1. Pemeriksaan Hematologi Pasien

\begin{tabular}{ccc}
\hline Pemeriksaan & Hasil & Standar \\
\hline $\mathrm{WBC}\left(10^{3} / \mu \mathrm{L}\right)$ & 13.6 & $5.5-19.5$ \\
\hline $\mathrm{RBC}\left(10^{6} / \mu \mathrm{L}\right)$ & 7.88 & $5.0-10.0$ \\
\hline $\mathrm{Hb}(\mathrm{g} / \mathrm{dL})$ & 10.9 & $8.0-15.0$ \\
\hline $\mathrm{HCT}(\%)$ & 40.7 & $24.0-45.0$ \\
\hline $\mathrm{MCV}(\mathrm{fL})$ & 51.7 & $39.0-55.0$ \\
\hline $\mathrm{MCH}(\mathrm{Pg})$ & 13.8 & $12.5-17.5$ \\
\hline $\mathrm{MCHC}(\mathrm{g} / \mathrm{dL})$ & $\mathbf{2 6 . 8} \downarrow$ & $\mathbf{3 0 . 0}-\mathbf{3 6 . 0}$ \\
\hline $\mathrm{PLT}\left(10^{3} / \mu \mathrm{L}\right)$ & 385 & $300-800$ \\
\hline Limfosit $(\%)$ & $\mathbf{1 9 . 8} \downarrow$ & $\mathbf{2 0 . 0}-\mathbf{5 5 . 0}$ \\
\hline Monosit $(\%)$ & 3.4 & $1.0-4.0$ \\
\hline
\end{tabular}

\begin{tabular}{ccc}
\hline Pemeriksaan & Hasil & Standar \\
\hline Granulosit $(\%)$ & 76.8 & $35.0-78.0$ \\
\hline Limfosit $\left(10^{3} / \mu \mathrm{L}\right)$ & 2.7 & $1.5-7.0$ \\
\hline Monosit $\left(10^{3} / \mu \mathrm{L}\right)$ & 0.5 & $0.0-0.85$ \\
\hline Granulosit $\left(10^{3} / \mu \mathrm{L}\right)$ & 10.4 & $2.5-14$ \\
\hline RDW-CV $(\%)$ & 15.6 & $13.0-17.0$ \\
\hline RDW-SD $(\mathrm{fL})$ & 36.1 & $35-56$ \\
\hline PCT $(\%)$ & 0.45 & $0.0-2.9$ \\
\hline MPV (fL) & $\mathbf{1 1 . 7} \downarrow$ & $\mathbf{1 2 . 0 - 1 7 . 0}$ \\
\hline PDW $(\mathrm{fL})$ & 13.7 & $10.0-18.0$ \\
\hline P-LCR (\%) & $\mathbf{4 8 . 5} \uparrow$ & $\mathbf{1 3 - 4 3}$ \\
\hline
\end{tabular}

Pemeriksaan darah dengan tujuan melakukan evaluasi pasien dilakukan pada minggu kedua perawatan setelah pengobatan gentamicin. Hasil pemeriksaan darah menunjukkan kondisi pasien yang tidak mengalami gangguan secara signifikan dan berada dalam kondisi baik. Perubahan yang timbul mencakup penurunan $\mathrm{MCHC}$ dan peningkatan P-LCR disertai limfopenia dan penurunan MPV yang tidak signifikan. Berkurangnya nilai MCHC dapat disebabkan oleh retikulositosis, penurunan hemoglobin akibat defisiensi zat besi, dan defisiensi vitamin B6, tetapi tidak memiliki pengaruh signifikan terhadap pasien. Kondisi limfopenia pada pasien tidak signifikan dan 
dapat disebabkan akibat proses peradangan pada mata pasien, dimana limfositopenia dapat terjadi baik karena peradangan, gangguan produksi, maupun akibat pengaruh steroid (Maria and Ioannis, 2016). Penurunan rataan nilai platelet dapat diakibatkan oleh kerusakan jaringan selama proses inflamasi, dimana megakaryosit menghasilkan platelet dalam jumlah besar sehingga terjadi reduksi ukuran platelet yang dihasilkan (Korniluk et al., 2019). Hasil P-LCR meningkat dapat menunjukkan bahwa terdapat platelet yang melebihi dari ukuran rata-rata normal dari hasil penghitungan platelet total, yang dapat mengindikasikan terjadinya stimulus terhadap aktivasi platelet (Gawlita et al, 2016). Temuan tersebut dapat mengindikasikan peningkatan aktivitas platelet dalam proses penutupan luka, dimana pada pasien terjadi perlukaan pada bagian mata tanpa disertai perdarahan sehingga kondisi sel darah merah tidak terpengaruhi oleh penyakit pasien.
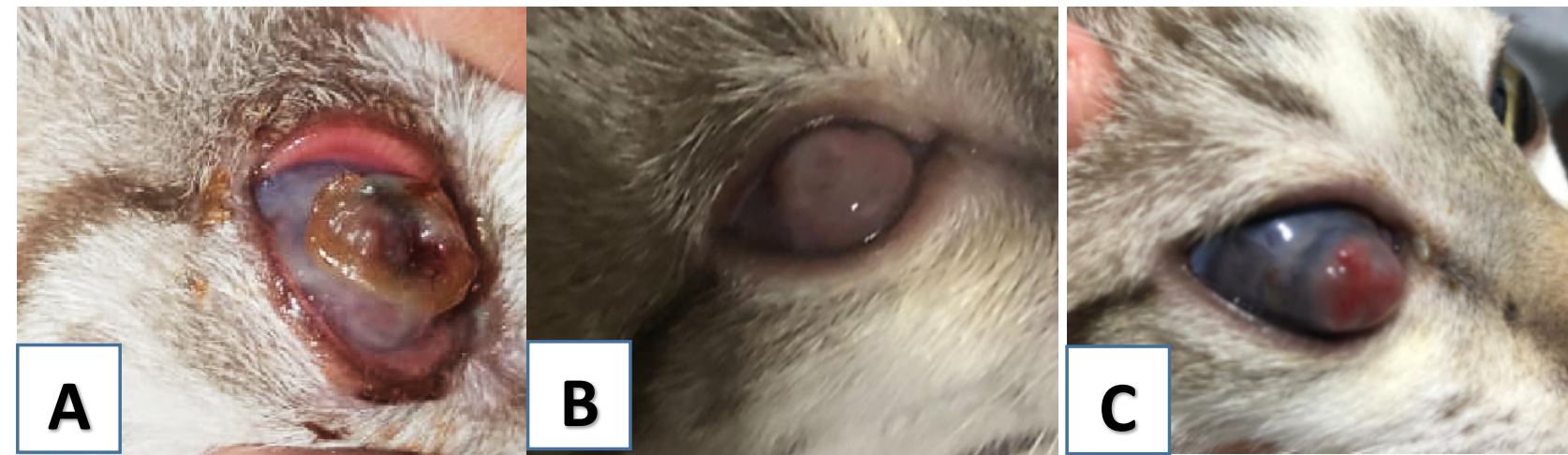

Gambar 1. Kondisi Mata Kanan Pasien. A. Kondisi awal pasien, B. Kondisi pasien minggu ke-1, dan C. Kondisi pasien minggu ke-2

Pasien mengalami perubahan pada kondisi mata yang fluktuatif seiring masa perawatan. Kondisi mata pasien terlihat penuh dengan kerak (Gambar 1A) pada awal pemeliharaan dan dilakukan pembersihan berkala disertai terapi gentamicin dan pemberian $\mathrm{NaCl}$ 0,9\% secara berkala. Pasien tidak mengalami pembentukan eksudat dan berkurangnya konjungtivitis. Pembentukan eksudat yang melapisi mata kembali terlihat pada hari ke 7 pemeliharaan setelah penghentian gentamicin pada hari ke-5

(Gambar 1B). Terapi kembali dilakukan 
selama 5 hari menggunakan gentamicin disertai pemberian $\mathrm{NaCl}$ 0,9\% yang diberikan secara berkala. Pembentukan eksudat dan peradangan terhenti setelah dilakukan terapi gentamicin pada minggu ke-2 (Gambar 1C). Ukuran mata yang terhitung dari canthus lateral hingga prolaps iris mengalami penyusutan sebesar $0,2 \mathrm{~cm}$ selama 2 minggu pemeliharaan dan tidak mengalami penyusutan kembali maupun perubahan ukuran prolaps. Tindakan yang dianjurkan dalam penanganan lanjutan kasus ini adalah prosedur enukleasi untuk meningkatkan taraf hidup pasien.

Pelaksaanaan prosedur invasif disarankan akibat perkembangan yang kurang baik dari pendekatan menggunakan terapi kuratif pada kondisi mata pasien. Tidak terbentuk kerak yang intensif disertai berkurangnya penonjolan iris sebesar $0,2 \mathrm{~cm}$. Setelah pengobatan antibiotik dihentikan, dalam waktu 36 jam, pembentukan eksudat dari mata terjadi kembali sehingga diputuskan untuk melakukan regimen pengobatan antibiotik kembali sembari menunggu hasil pemeriksaan darah dan persiapan operasi.

\section{KESIMPULAN}

Prolapsus iris merupakan kondisi dimana iris yang melayang di dalam bilik anterior mata mengalami gangguan sehingga tertarik menuju daerah ekstraokuler. Temuan klinis mengindikasikan terjadinya prolaps iris disertai konjungtivitis yang menghasilkan eksudat. Pengobatan dilakukan dengan melembabkan daerah pada mata terdampak dan pemberian antibiotik untuk menuntaskan peradangan. Penggunaan agen anti-inflamasi steroid maupun NSAID tidak dianjurkan karena potensi dalam menimbulkan ulkus dan memperlambat penyembuhan kornea. Pemberian terapi yang meredakan gejala simptomatik pasien dapat mengurangi keparahan prolaps iris secara tidak signifikan sehingga disarankan untuk melanjutkan penangan pada prosedur enukleasi.

\section{UCAPAN TERIMA KASIH}


Tulisan ini dibuat dengan persetujuan dari klien selaku penyelamat hewan yakni saudari Citra. Rasa terima kasih diucapkan kepada drh. Ajeng Aeka, M. Sc yang berkenan memberi masukan beserta segenap keluarga besar RSHP Universitas Brawijaya yang telah memberi fasilitas penunjang dalam pelaksanaan pengobatan. Terimakasih kepada drh. Winda selaku pemberi pelayanan medis enukleasi sehingga pasien dapat kembali sehat seutuhnya.

\section{DAFTAR PUSTAKA}

Barabino, S., M., Rolando, P., Camicione, W., Chen, and G., Calabria. 2006. Effects of a $0.9 \%$ sodium chloride sophthalmic solution on the ocular surface of symptomatic contact lens wearers. Can. J. Ophthalmol.; 40: 45-50

Englar, E. Ryane. 2019. Common clinical presentation in dogs and cats. John Wiley and Sons. New Jersey.

Gawlita, M., J., Wasilewski, T., Osadnik, R., Regula, K., Bujak, and M., Gonera. 2016. Mean platelet volume and platelet large cell ratio as prognostic factors for coronary artery disease and myocardial infarction. Folia cardiologia; 10(6): 418422

Iwamoto, S., T., Koga, M., Ohba, T., Okuno, M., Koike, A., Murakami, A., Matsuda and T., Yokomizo. 2017. Non-steroidal antiinflamatory drug delays corneal wound healing by reducing production of $12-$ hydroxyheptadecatrienoic aid, a ligand for Leukotriene $\mathrm{B}_{4}$, receptor 2 . Scientific Reports; 7: 13267

Johnson, M. E., P. J., Murphy, and M., Boulton. 2006. Effectiveness of sodium hyaluronate eyedrops in the treatment of dry eye. Graefe's Arch Clin. Exp. Ophthalmol.; 244: 109-112

Korniluk, A., O. M., Koper-Lenkiewicz, J., Kaminska, H., Kemona, and V., Dymicka-Piekarska. 2019. Mean Platelet Volume (MPV): New Perspectives for an Old Marker in the Course and Prognosis of Inflammatory Conditions. Mediators of Inflammation; 1: 1-14

Maria, K. and L.O., Ioannis. 2016. The interpretation of leukogram in dog and

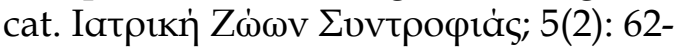
68

Maddison, E. Jill, S. W., Page, and D. B., Church. 2008. Small animal clinical pharmacology. 2nd Edition. Saunders. London

Plumb, C. Donald. 2008. Plumb's Veterinary Drug Handbook. $6^{\text {th }}$ Edition. Blackwell Publishing. Iowa

Turner, M. Sally. 2009. Saunders Solutions in Veterinary Practice: Small Animal Ophtalmology. Saunders Elsevier. China

Roze, Maurice. 2005. Ocular Manfestation of Feline Systemic Disease. WSAVA Congress Proceedings. WSAVA. Marseille.

Sarchahi A.A., A. M., Parizi, M., Eghtedan, and S., Keshavars. 2011. Effect of different treatment regimen with dexamethason and acetylcysteine on corneal wound healing in rabbits. Iranian Journal of Medical Science; 36(3): 188-95 
Williams, L. 2008. Immunopathogenesis of Keratoconjucntivitis Sicca in the Dog. Vet. Clin. Small. Anim.; 38: 251-268

Williams, L. David. 2014. Obvious Ophtalmology: corneal ulceration. Vetcpd; 1: 28-33 